\title{
Pentingnya Orang Dewasa Awal Menyelesaikan Tugas Perkembangannya
}

\author{
Alifia Fernanda Putri \\ Universitas Negeri Padang \\ *)Correspondence regarding this article should be addressed to: Author address e-mail: \\ alifia.fernanda@gmail.com
}

\begin{abstract}
Abstrak: Dalam menghadapi kehidupan orang dewasa awal wajib menyelesaikan tugas perkembangannya agar dalam menjalani kehidupan sehari-hari tidak mengalami masalah yang berarti serta tidak mengganggu proses masa perkembangan selanjutnya. Masa dewasa awal merupakan transisi dari masa remaja yang masih menjalani kehidupan yang hura-hura menuju masa yang menuntut akan rasa tanggung jawab. Perkembangan masa dewasa awal ini di mulai saat seseorang menginjak pada umur 19 tahun sampai 25 tahun. Tidak dipungkiri dalam masa dewasa awal sangat rentan mengalami permasalahan, hal ini bisa saja dipengaruhi oleh faktor internal maupun eksternal seperti faktor lingkungan, masyarakat, teman sebaya dan lainnya. Dalam masa dewasa awal banyak sekali masalasah yang dihadapi dalam menjalani kehidupannya, baik dari segi individu, sosial, fisik, budaya maupun yang lainnya. Oleh karena itu sangatlah dibutuhkan peran maupun bantuan dari seorang guru BK atau konselor dalam membimbing orang dewasa awal dalam melaksanakan tugas perkembangannya agar orang dewasa awal bisa menyelesaikan tugas perkembangannya dengan seoptimal mungkin agar mendapatkan kehidupan yang bahagia kedepannya.
\end{abstract}

Kata kunci: Tugas dewasa awal, peran guru BK maupun Konselor

Article History: Received on 05/07/2019; Revised on 07/08/2019; Accepted on 17/08/2019; Published Online: $31 / 08 / 2019$.

(c) (1) This is an open access article distributed under the Creative Commons Attribution License, which permits unrestricted use,
distribution, and reproduction in any medium, provided the original work is properly cited. (2019 by author.

Setiap orang akan menjalani tugas-tugas perkembangannya mulai dari anakanak, remaja, orang dewasa sampai ke lansia. Ada beberapa tugas perkembangan yang harus dilalui agar kehidupan menjadi bahagia dan tidak mengalami permasalahan yang berarti, khususnya bagi orang dewasa awal, karena masa dewasa awal ini masa puncaknya perkembangan bagi setiap orang. Istilah adult atau dewasa berasal dari kata kerja latin yang bererti tumbuh menjadi dewasa. Oleh karena itu orang dewasa adalah seseorang yang telah menyelesaikan pertumbuhannya dan siap menerima kedudukannya di masyarakat bersama orang dewasa lainnya (Hurlock, 1996). Masa dewasa awal dimulai pada umur 18 tahun sampai kira-kira 40 tahun. Saat perubahan-perubahan fisik dan psikologis yang menyertai berkurangnya kemampuan reproduktif (Hurlock, 1996). Masa dewasa awal merupakan periode penyesuaian diri terhadap pola-pola kehidupan yang baru dan harapan-harapan sosial baru. Orang dewasa awal diharapkan memainkan peran baru, seperti suami/istri, orang tua , dan pencari nafkah, keinginan-keinginan baru, 
mengembangkan sikap-sikap baru dan nilai-nilai baru sesuai tugas baru (Hurlock, 1996). Sedangkan menurut Mappiare (1983:15) orang dewasa awal merupakan transisi baik secara fisik, intelektual, peran sosial dan psikologis yang menyertai berkurangnya kemampuan reproduktif.

Dewasa awal merupakan masa peralihan dari masa remaja menuju masa dewasa. Peralihan dari ketergangungan kemasa mandiri baik dari ekonomi, kebebasan menentukan diri, dan pandangan masa depan lebih realistis. Secara hukum seseorang dapat dikatakan sebagai orang dewasa awal saat menginjak usia 21 tahun sampai berusia 21 tahun. lain pula yang kikatakan oleh Santrock (2011) bahwa Masa dewasa awal adalah istilah yang kini digunakan untuk menunjuk masa transisi dari remaja menuju dewasa. Rentang usia ini berkisar antara 18 tahun hingga 25 tahun, masa ini ditandai oleh kegiatan bersufat eksperimen dan eksplorasi. Transisi dari masa remaja menuju masa dewasa diwarnai dengan peruhan yang berkesinambungan.

Masa dewasa awal adalah masa pencarian, penemuan, pemantapan dan masa reproduktif, yaitu suatu masa yang penuh dengan masalah dan ketegangan emosional, periode isolasi sosial, periode komitmen dan masa ketergantungan, perubahan nilai-nilai, kreativitas dan penyesuaian diri pada ola hidup yang baru. Sebagai seorang individu yang sudah tergolong dewasa, peran dan tanggung jawabnya tentu makin bertambah besar. Dimana sudah mulai melepaskan diri dari ketergantungan terhadap orang lainn terutama dari orang tua, baik secara ekonomis, sosiologis ataupun psikologis. Mereka akan lebih mengupayakan untuk menjadi orang yang lebih mandiri lagi, segala upaya akan dilakuan agar tidak bergantung lagi kepada orang lain. Seperti yang diungkapkan oleh Erkson (dalam Monks, Knoers \& Haditono, 2001) bahwa tahap dewasa awal yaitu antara usia 20 tahun samapi 30 tahun. Pada tahap ini manusia mulai menerima dan memikul tanggung jawab yang lebih berat, pada tahap ini pula hubungan intim mulai berlaku dan berkembang. Individu yang tergolong dewasa awal ialah mereka yang berusia 20-40 tahun, mereka memiliki peran dan tanggung jawab yang tentu saja semakin besar. Individu tidak harus bergantung secara ekonomis, sosiologis maupun fisiologis pada orang tuanya (Dariyo, 2003).

Secara fisik, seorang dewasa awal menunjukkan penampilan yang sempurna dalam arti bahwa pertumbuhan dan perkembangan aspek-aspek fisiologis telah mencapai posisi puncak. Mereka memiliki daya tahan dan taraf kesehatan yang prima sehingga dalam melakukan berbagai kegitan tampak inisiatif, kreatif, energik, cepat, dan proaktif.

Berdasarkan pendapat para tokoh diatas dapat disimpulkan bahwa dewasa awal adalah masa dimana individu siap berperan dan bertanggung jawab serta menerima kedudukan dalam masyarakat, masa untuk bekerja, terlibat dalam hubungan sosial masyarakat dan menjalin hubungan dengan lawan jenis.

Dewasa awal merupakan masa transisi dari masa remaja sehingga ciri-ciri perkembangan masa dewasa awal tidak begitu berbeda dari masa remaja. Ciri-ciri masa dewasa menurut Hurlock (1996) yaitu: (a) masa dewasa awal merupakan suatu usia reproduktif, masa ini ditandai dengan membentuk rumah tangga. Pada masa ini khususnya wanita, sebelum usia 30 tahun, merupakan masa reproduktif, dimana seseorang wanita siap menerima tanggung jawab sebagai seorang ibu. Pada masa ini, alat-alat reproduksi manusia telah mencapai kematangannya dan sudah siap untuk 
melakukan reproduksi. (b) masa dewasa awal sebagai masa bermasalah, setiap masa dalam kehidupan manusia, pasti mengalami perubahan, sehingga seseorang harus banyak melakukan kegiatan penyesuaian diri dengan kehidupan perkawinan, peran sebagai orang tua dan sebagai warga negara yang sudah dianggap dewasa secar hukum. (c) masa dewasa awal merupakan masa yang penuh dengan masa ketegangan emosional, ketegangan emosional seringkali ditempatkan dalam ketakutan-ketakutan atau kekhawatiran-kekhawatiran. Ketakutan atau kekhawatiran yang timbul ini pada umumnya bergantung pada tercapainya penyesuaian terhadap persoalan yang dihadapi pada suatu saat tertentu atau sejauh mana sukses atau kegagalan yang dialami dalam penyelesaian persoalan. (d) masa dewasa awal sebagai masa ketergantungan dan perubahan nilai, ketergantungan disini mungkin ketergantungan kepada orang tua, lembaga pendidikan yang memberikan beasiswa atau pada pemerintahan karana mereka memperoleh pinjaman untuk membiayai pendidikan mereka, sedangkan masa perubahan nilai masa dewasa awal terjadi karena beberapa alasan seperti ingin diterima pada kelompok orang dewasa, kelompok orang dewasa, kelompok-kelompok sosial dan ekonomi orang dewasa.

Sedangkan menurut Anderson (dalam Mappiare) ada beberapa ciri-ciri orang dewasa awal adalah: (a) berorientasi pada tugas, bukan pada diri atau ego, minat orang matang berorientasi pada tugas-tugas yang dikerjakannya, dan tidaak condong pada perasaan-perasaan diri sendiri atau untuk kepentingan pribadi. (b) tujuan-tujuan yang jelas dan kebiasaan-kebiasaan yang efisien, seseorang yang matang melihat tujuan-tujuan yang ingin dicapainya secara jelas dan tujuan-tujuan itu dapat didefinisikannya secara cermat dan tahu mana yang pantas dan yang tidak serta bekerja secara terbimbing menuju arahnya. (c) mengendalikan perasaan pribadi, seseorang yang matang dapat menyetir perasaan-perasaan sendiri yang tidak dikuasai oleh perasaan-perasaannya dalam mengerjakan sesuatu atau berhadapan dengan orang lian. Dia tidak mementingkan dirinya sendiri, tetapi mempertimbangkan pula perasaan-perasaan orang lain. (d) keobjektifitas, orang matang memiliki sikap objektif yaitu berusaha mencapai keputusan dalam keadaan yang bersesuaian dengan kenyataan. (e) menerima kritik dan saran, orang matang memimiliki kemauan yang realistis, paham bahwa dirinya tidak selalu benar, sehingga terbuka terhadap kritik-kritik dan saran-saran orang lian demi peningkatan dirinya. (f) pertanggungjawaban terhadap usaha-usaha pribadi, orang yang matang mau memberi kesempatan pada orang lian membantu usaha-usahanya untuk mencapai tujuan. $(\mathrm{g})$ penyesuaian yang realistis terhadap situasi-situasi baru.

\section{Pembahasan}

\section{Tugas Perkembangan Dewasa Awal}

Dalam menjalani kehidupannya orang dewasa awal sangat perlu dan penting dalam menyelesaikan tugas perkembangannya, agar dalam kehidupannya tidak mengalami masalah yang berarti dan merasa bahagia menjalani kehidupan yang akan dijalani selanjutnya. Hurlock (2009) membagi tugas perkembangan dewasa awal, antara lain, sebagai berikut: (a) mendapatkan suatu perkerjaan, (b) memilih seorang teman hidup, (c) belajar hidup bersama dengan suami istri membentuk suatu keluarga, (d) membesarkan anak-anak, (e) mengelolasebuah rumah tangga, ( $f$ ) menerima tanggung jawab sebagai warga negara, ( $g$ ) bergabung dalam suatu kelompok sosial. Adapun tugas perkembangan orang dewasa awal 
meurut R. J. Havighurs, 1953 ( dalam Hurlock, 1996) sebagai berikut: (a) memilih teman hidup, pada umumnya, pada masa dewasa awal ini individu sudah mulai berfikir dan memilih pasangan yang cocok dengan dirinya, yang dapat mengerti pikiran dan perasaanya, untuk kemudian dilanjutkan dengan pernikahan. (b) belajar hidup bersama suami istri, masing-masing individu mulai menyesuaikan baik pendapat, keinginan, dan minat dengan pasangan hidupnya.

Mulai hidup dengan keluarga atau hidup dalam keluarga atau hidup bekeluarga. (c) mulai hidup dalam keluarga atau hidup bekeluarga, dalam hal ini masing-masing individu sudah mulai mengabaikan keinginan atau hak-hak pribadi, yang menjadi kebutuhan atau kepentingan yang utama adalah keluarga. (d) dituntut adanya kesamaan cara serta paham, hal ini dilakukan agar anak tidak merasa bingung harus mengikuti cara ayah atau ibunya. Maka dalam hal ini pasangan suami istri harus menentukan bagaimana pola asuh dalam mendidik anak-anaknya. (e) mengelola rumah tangga, dalam mengelola rumah tangga harus ada keterusterangan antara suami istri, hal ini untuk menghindari percecokan dan konflik dalam rumah tangga. (f) mulai bekerja dalam suatu jabatan, seseorang yang sudah memasuki masa dewasa awal dituntut untuk dapat memenuhi kebutuhannya sendiri, yaitu dengan jalan bekerja. Dalam pekerjaanya tersebut, individu dituntut untuk dapat menyesuaikan diri dengan lingkungannya. ( $g$ ) mulai bertanggung jawab sebagai warga negara secara layak, seseorang yang dikatakan dewasa sudah berhak untuk menentukan cara hidupnya sendiri, termasuk dalam hal ini hak dan kewajibannya sebagai warga dari suatu negara. (h) memperoleh kelompok sosial yang seirama dengan nilai-nilai atau pahamnya, setiap individu mempunyai nilai-nilai dan faham yang berbeda satu sama lain. Pada masa ini seorang individu akan mulai mencari orang-orang atau kelompok yang mempunyai faham yang sama atau serupa dengan dirinya.

Setiap individu memliki tugas-tugas perkembangan pada setipa fase kehidupannya, termasuk orang dewasa awal, dan setipa tugas perkembangan tersebut akan semakin sulit sesuai tahap perkembangan indivudu tersebut, oleh karena itu individu harus bisa menyelesaiakannya dengan sebaik mungkin. Tugas perkembangan yang disebutkan oleh para ahli diatas harus bisa dilaksanakan oleh orang dewasa awal , keberhasilan dalam menjalani tugas-tugas perkembangan tersebut akan membawa dan menimbulkan kebahagiaan dan mengarahkan kepada keberhasilan dalam melaksankan tugas-tugas perkebangan pada fase-fase selanjutnya, sebaliknya jika individu tersebut gagal dalam melaksakan tugas perkembnagannya maka akan mengantarkannya pada ketidakbahagiaan dan akan mengacaukan tugas perkembangan yang akan dijalani selanjutnya.

\section{Peran Guru Bk atau Konselor dalam Membimbing Dewasa Awal Melaksanakan Tugas Perkembagannya}

Masa dewasa awal merupakan masa yang sangat penting dan berharga bagi fase perkembangan seseorang, oleh karena itu setiap individu harus bisa melaksakan atau menyelesaikan tugas perkembangan tersebut dengan sangat baik. Dalam melaksakan tugas perkembangan tersebut orang dewasa awal akan menemukan beberapa hambatan dalam proses pelaksanaan tugasnya, maka dari itu sangat dibutuhkan peran dari seorang guru BK maupun konselor dalam membantu dan membimbing orang desawa awal dalam proses pelaksanaan tugas perkembangannya tersebut agar tidak terjadi hal-hal yang tidak diinginkan dan yang akan merugikan individu itu sendiri. Sesuai yang dikatakan oleh 
Tohirin (2007:36-37) bahwa tujuan bimbingan dan konseling yaitu memperoleh pemahaman yang lebih baik terhadap diri klien sesuai dengan potensi yang dimilikinya, mampu memecahkan sendiri masalah yang dihadapi klien, dapat menyesuaikan diri secara lebih efektif baik terhadap dirinya sendiri maupun lingkungannya sehingga memperoleh kebahagian dalmnya. Sedangkan menurut Prayitno dan Erman Amti (2004:130) bimbingan dan konseling memiliki tujuan yang terdiri atas tujuan umum dan khusus. Tujuan umum bimbingan dan konseling membantu individu agar dapat mencapai perkembangan secara optimal sesuai dengan bakat, kemampuan, minat dan nilai-nilai, serta terpisahnya masalah-masalah yang dihadapi klien. Termasuk tujuan umum bimbingan dan konseling adalah membantu individu agar dapat mandiri dengan ciri-ciri mampu memahami dan menerima dirinya sendiri dan lingkungannya, membuat keputusan dan rencana yang realistik, mengarahkan diri sendiri dengan keputusan dan rencananya itu serta pada akhirnya memujudkan diri sendiri. Sesuai dengan apa yang telah dikatakan oleh para ahli diatas bahwasanya tujuan bimbingan dan konseling adalah supaya individu yang dibimbing dapat menjadi lebih mandiri dan bisa menetapkan pilihan yang sesuai dengan bakat minat dan potensi yang dimiliki klien.

Sesuai dengan tujuan bimbingan dan konseling diatas yang berkaitan dengan permasalahan orang dewasa awal maka Guru BK maupun konselor dapat: (a) memaksimalkan perkembangan dan kemampuan memecahkan masalah pada orang dewasa awal dan membantu orang dewasa awal tersebut mngeksplorasi berbagai kemampuan yang dimiliki. (b) guru BK maupun konselor dapat mencari informasi yang dapat dibagikan kepada orang dewasa awal, misalnya dalam hal pekerjaan, maka guru Bk maupun konselor dapat mencari informasi yang seakurat mungkin mengenai lapangan pekerjaan yang tersedia dan yang sesuai dengan individu tersebut, cara pemberiakn informasi tersebut yaitu melalui layanan informasi, baik dilakukan secara individu maupun klasikal. (c) selain itu guru BK maupun Konselor harus memiliki pemahan yang luas mengenai orang dewasa awal, baik mengenai perkembangan fisik,kognitif dan fisiologisnya, misalnya orang dewasa tersebut ingin menikah tapi masih bingung akan keputusan menikah tersebut maka konselor harus memiliki pemahaman yang luas mengenai pernikahan tersebut dan hal apa saja yang akan ditemui oleh individu tersebut setelah menikah.

\section{KESIMPULAN}

Masa dewasa awal merupakan masa puncak dari perkembangan seseorang individu, masa dewasa awal merupan masa transisi dari masa remaja yang masih dalam kedaan bersenang-senang dengan kehidupan. Pada masa dewasa awal ini individu akan banyak menemui permasalahan dalam hidup dan permasalahan tersebut harus bisa diselesaikan dengan baik. Adapun tugas perkembangan masa dewasa awal adalah: memilih pasangan hidup, mencapai peran sosial, bertanggung jawab, mencapai kemandirian emosional, belajar membangun kehidupan rumah tangga dengan pasangan hidup, mengasuh anak, dan menjadi warga negara yang baik.

Peran dari guru BK maupun konselor adalah mampu mengarahkan klien kepada peningkatan kemampuan dan perkembangan individu agar tercapai tugas perkembangan dan individu tersebut dapat melaksanakan tugas perkembangannya dengan baik. Dengan 
tercapainya tugas perkembangan tersebut diharapkan kehidupan klien dapat menjadi bahagia dan tidak mengalami permasalahan dalam melaksanakan tugas perkembangan selanjutnya.

\section{REFERENCES}

Dariyo, Agoes. (2003). Psikologi Perkembangan Dewasa Muda. Jakarta: Gramedia Pustaka.

Hurlock, E. B. (1996). Psikologi Perkembangan. Jakarta: Erlangga.

Mappiare, Andi. (1983). Psikologi Orang Dewasa. Surabaya: Usaha Nasional.

Monks, F. J, Knoers, A. M. P \& Haditono, S. R. (2001). Psikologi Perkembangan: Pengantar Dalam Berbagai Bagiannya. Yogyakarta: Gadjah Mada University Press.

Prayitno \& Erman, Amti. (2004). Dasar-Dasar Bimbingan dan Konseling. Jakarta: Rineka Cipta.

Santrock, J, W, (2011). Life-Span Development (Perkembangan Masa Hidup) Jakarta:Erlangga.

Tohirin. 2007. Bimbingan dan Konseling di Sekolah dan Madrasah (Berbasis Integrasi) jakarta: Raja Grafindo Persada. 